\title{
Educational Attainment in a High Performing School District: The Relative Significance of Class ${ }^{1}$
}

\author{
Enrique S. Pumar ${ }^{2}$ \\ Adam Sitsis $^{3}$
}

Our paper examines the class inequalities among racial and ethnic groups to account for the different levels of educational attainment in suburban school districts. To examine this question, we chose what many consider one of the most successful school districts in the nation and followed a within case comparison of class along racial and ethnic lines. Our findings illustrate how by inserting class considerations one can predict different levels of human capital within groups. This finding calls attention to the need to incorporate class analysis to account for educational opportunities within similar demographic groups. [Article copies available for a fee from The Transformative Studies Institute. E-mail address: journal@transformativestudies.org Website: http://www.transformativestudies.org (C2012 by The Transformative Studies Institute. All rights reserved.]

KEYWORDS: Class, Educational Attainment, Suburban Schools, Race and Ethnic Groups.

\footnotetext{
${ }^{1}$ The first draft of this paper was prepared for the session entitled Race and Class in Educational Attainment of the 2011 Annual Meeting of the Eastern Sociological Society in Philadelphia on February 24-27. We thank the members of the panel, particularly our discussant Professor Faye Glass, for the questions and discussion from which have benefited a great deal when we set out to revise this paper.

${ }^{2}$ Enrique S. Pumar, Ph.D., is Associate Professor and Chair of the Department of Sociology and Faculty Fellow at the Institute for Policy Research and Catholic Studies at The Catholic University of America. Dr. Pumar has published extensively in the areas of political sociology, urbanization, and migration and ethnic studies. He is contributing editor for sociology to the Library for Congress Handbook of Latin American Studies and is currently a member of the study groups on international migration and towns and cities both at the Interactivity Foundation. Address correspondence to: Dr. Enrique S. Pumar, Catholic University, Dept. of Sociology, Aquinas Hall 116, Washington, DC 20064.

${ }^{3}$ Adam Sitsis is a Doctoral Candidate in Sociology at George Mason University. During his undergraduate and Master studies at Catholic University he worked closely in multiple projects with Dr. Enrique S. Pumar.
} 